\title{
Marzenna Wiśniewska
}

Uniwersytet Mikołaja Kopernika w Toruniu

\section{OTWARTE ARCHIWUM DORMANA}

W roku 1976 na łamach „Pamiętnika Teatralnego” (z. 3) ukazał się artykuł Henryka Jurkowskiego Teatr Dzieci Zagłębia 1945-1974, poświęcony autorskiej i awangardowej działalności teatralnej Jana Dormana. Artysta był wtedy u szczytu kariery reżyserskiej, przylgnęło już do niego określenie enfant terrible polskiego teatru lalek, utrwalone między innymi dzięki takim spektaklom jak Szczęśliwy ksiązę Oscara Wilde'a (Teatr Dzieci Zagłębia w Będzinie, 1967), Optymizm, czyli Kandyd: widz naiwny Voltaire'a (Teatr Lalka w Warszawie, 1972) oraz przewrotnej i potraktowanej przez środowisko lalkarskie jako skandal akcji happeningowej na Ogólnopolskim Festiwalu Teatrów Lalek w Opolu Choinka futurystów lub kolej na bunt przedmiotów według Włodzimierza Majakowskiego (1973). Doceniając „konsekwentne i bezkompromisowe poszukiwanie nowego wyrazu teatralnego”, Tadeusz Kudliński stawiał Dormana obok Jerzego Grotowskiego i Tadeusza Kantora. ${ }^{1}$ Szczegółową analizę tego okresu twórczości artysty, a dokładnie do roku 1977, czyli do zakończenia dyrekcji w stworzonym przez niego Teatrze Dzieci Zagłębia w Będzinie i przejścia na emeryturę, dała Ewa Tomaszewska w dwóch tomach monograficznych Jan Dorman - poeta teatru (Katowice 2019) i Jan Dorman - wtasna droga (Katowice 2012). Dotychczas jednak nie powstało opracowanie obejmujące ostatnią dekadę działalności teatralnej Dormana (do 1986), a był to dla niego intensywny czas pracy artystycznej na wielu polach: współpracował z teatrami w całej Polsce, stworzył 19 premier, kolejne 2 były w przygotowaniu, reżyserował opery, uczestniczył w powołaniu teatru w Tychach, realizował awangardowe spektakle dyplomowe ze studentami Wydziału Lalkarskiego wrocławskiej filii PWST (dziś Akademii Sztuk Teatralnych), a żywioł eksperymentalności tych doświadczeń przenosił do inscenizacji, które konsekwentnie rozwijały jego model teatru dla młodzieży. W tym czasie przygotował retrospektywne wystawy i przeglądy swojej twórczości (m.in. „Off-Off Broadway” w Zakopanem, 1981; I Spotkania Wizji i Plastyki w Katowicach, 1986), regularnie uczestniczył w dyskusjach środowiskowych

T. Kudliński, Vademecum teatromana, Warszawa 1973, s. 293. 
i zapisywał swoje idee teatralne. Prezentowany zeszyt monograficzny „Pamiętnika Teatralnego" powstał jako efekt rezydencji badawczych, które miały na celu rozpoznanie właśnie tej części działalności teatralnej Dormana i rozpoczęcie procesu uzupełniania brakującej karty historii jego teatru. A było to możliwe przede wszystkim dzięki otwartemu dostępowi do ogromnej i bogatej w różne typy dokumentacji spuścizny archiwalnej, którą do końca swojego życia skrupulatnie wytwarzał sam Dorman, którą potem chroniła i popularyzowała córka będzińskiego reżysera, Iwona Dowsilas ${ }^{2}$, i która wreszcie w 2016 trafiła do Instytutu Teatralnego im. Zbigniewa Raszewskiego w Warszawie.

Przekazanie Archiwum Dormana pod opiekę Instytutu Teatralnego było pokłosiem Teatralnego placu zabaw Jana Dormana (2012), autorstwa pedagożek teatru, Justyny Sobczyk i Justyny Lipko-Koniecznej, które tym objazdowym spektaklem i towarzyszącymi im warsztatami oraz publikacjami metodycznymi ponownie włączyły teksty teatralne i filozofię teatru dla dzieci i młodzieży Dormana w krwiobieg dzisiejszego życia teatralnego. Dostęp do całości zbiorów Archiwum Dormana ujawnił jego ogromny potencjał dla badaczy i praktyków teatru - artysta pozostawił po sobie bogatą dokumentację teatralną i osobistą, rękopisy, maszynopisy, notatki, rysunki, projekty scenograficzne, scenariusze, fotografie, artefakty (lalki, fragmenty dekoracji), korespondencję, nagrania dźwiękowe i filmowe. Szczególnym fenomenem tego archiwum jest rękopiśmienna dokumentacja każdej premiery, która była wynikiem oryginalnej formuły pracy reżyserskiej Dormana. Próby zaczynał on bez gotowego scenariusza, od inspiracji literackich, muzycznych, improwizacji $\mathrm{z}$ fragmentami tekstów lub przedmiotem, rytmem, przestrzenią, i dopiero w trakcie wspólnych działań scenicznych rodził się tekst przyszłego scenariusza. Reżyser odręcznie notował dialogi i monologi sceniczne na luźnych kartkach formatu A4, które potem sklejał (niekiedy z pomocą asystentów reżysera) w charakterystyczny sposób - wzdłuż dłuższego boku łączył wszystkie kartki w długą harmonijkę, podobnie do tego, jak przygotowuje się egzemplarz nutowy. Powstałe w ten sposób partytury teatralne $\mathrm{z}$ łatwością można było w trakcie prób rozłożyć na scenie w formie kilkumetrowego pasa, dającego reżyserowi i zespołowi wgląd w aktualną wersję tekstu i zadań aktorskich. Sam Dorman określał te harmonijkowe tomy dokumentacji pracy, które łączyły cechy scenariusza, egzemplarza reżyserskiego i dziennika pracy, słowem ,sklejka” i taki termin utrwalił się wśród lalkarzy oraz został przyjęty w opracowaniach badawczych. Wielotomowe zbiory sklejek

2 Zbiory te wędrowały po wielu miejscach. Najpierw Dorman gromadził archiwum w budynku Teatru Dzieci Zagłębia w Będzinie, porządkując materiały w ręcznie zrobionych segregatorach lub teczkach/sklejkach. Przymusowe przenosiny do prywatnych pomieszczeń rodziny Dormanów, najpierw w Sosnowcu, potem w Tychach i Będzinie, szczęśliwie zakończyły się powołaniem przez Iwonę Dowsilas Fundacji im. J. Dormana (1999), która w niewielkim pomieszczeniu budynku Muzeum Zagłębia w Będzinie uruchomiła Archiwum Dormana jako placówkę powołaną do gromadzenia, porządkowania, opisu i upowszechniania spuścizny teatralnej Dormana. Na podstawie wybranych części zbiorów Iwona Dowsilas wydała serię książek z wypisami z rękopisów oraz dokumentacji artystycznej, organizacyjnej i prywatnej Dormana. 
umożliwiają dziś analizowanie ewolucji idei interpretacyjnych Dormana, założeń teatralnych i koncepcji inscenizacyjnych każdej premiery, ale też atmosfery i życiowych okoliczności towarzyszących pracy nad spektaklem. Intrygują one zarówno swoją wewnętrzną zawartością, jak i kształtem materialnym. ${ }^{3}$ Zbiory te $-\mathrm{w}$ wielu aspektach porównywalne do archiwum Tadeusza Kantora - skłaniają ponadto do refleksji nad stosowanymi przez Dormana strategiami zapośredniczenia, utrwalania i wytwarzania pamięci, nad sposobami pozostawiania śladów artystycznych i biograficznych oraz nad samym gestem archiwalnym, widocznym choćby w formie materialnej dokumentacji, co z kolei umieszcza Archiwum Dormana w polu badań nad archiwum jako performansem i performatywnością archiwum. ${ }^{4}$

Świadomość złożonego potencjału archiwum Dormana zdecydowała o powołaniu w 2016 w Instytucie Teatralnym zespołu łączącego badaczki i pedagożki teatru (Justyna Sobczyk i Justyna Lipko-Konieczna - kuratorki, Marzenna Wiśniewska - kierownictwo naukowe, Wiktoria Siedlecka-Dorosz, Agata Łukaszewicz, Justyna Czarnota - koordynacja i opracowanie dokumentacji), który zainicjował trzyletni projekt pod nazwą „Dorman. Archiwum otwarte”. U jego podstaw legła koncepcja archiwum performatywnego, które przestaje być statycznym zbiorem, a może zostać wprawione w ruch i wytwarzać osobne performanse. Idea performowania archiwum przełożona została na program współpracy teoretyków i praktyków teatru, w konsekwencji którego doszło do przecinania się czterech pól: problematyki dokumentacji teatralnej, historii i teorii teatru, pedagogiki teatru i twórczości teatralnej. Archiwum Dormana wymagało uporządkowania, scalenia i kategoryzacji rozproszonej dokumentacji, wstępnego opracowania i opisu zasobów. Między innymi usystematyzowano chronologicznie dzienniki pracy, skompletowano według tytułów premier sklejki przedstawień zrealizowanych i spektakli projektowanych, ale niedokończonych, w całość zebrany został pokaźny zbiór polskiej i zagranicznej korespondencji Dormana, wyselekcjonowano poszczególne dokumenty dzieła: projekty scenograficzne, fotografie, programy, plakaty i inne druki teatralne. W toku jest konserwacja, digitalizacja i opis zachowanych nagrań dźwiękowych z Teatru Dzieci Zagłębia oraz innych miejsc działalności Dormana. Rozczytywanie rękopisów - z wydatną pomocą Iwony Dowsilas - pozwoliło wyłonić jego niepublikowane dotychczas teksty i zapiski. Wszystkie te prace były podstawą do rozpoczęcia procesu digitalizacji części zbiorów archiwum i opracowania koncepcji strony internetowej poświęconej artyście. Umożliwiły korektę i uzupełnienie danych dotyczących działalności teatralnej Dormana i wzbogacenie zasobów cyfrowych na platformach: e-teatr.pl oraz encyklopediateatru.pl.

\footnotetext{
Zob. M. Wiśniewska, Pisanie dla sceny i ,,sceny pisma” Jana Dormana, [w:] Pisanie dla sceny - narracje wspótczesnego teatru, red. M. Figzał-Janikowska, B. Popczyk-Szczęsna, E. Wąchocka, Katowice 2019.

4 Idea archiwum performatywnego na przykładzie Archiwum Dormana zob. M. Wiśniewska, Archiwum performatywne. Projekt „Dorman. Archiwim otwarte”, referat na konferencji „Dokumentacja przedstawień - między rejestracją a kreacją", Uniwersytet Śląski w Katowicach, 19-20 IV 2018 (w druku).
} 
Do końca 2017 zbiory archiwalne Dormana były przedmiotem pracy warsztatowej „Grupy roboczej” złożonej z badaczy, dramaturgów, reżyserów, aktorów, pedagogów teatru, twórców niezależnych. Inspiracje płynące ze zbiorów wykorzystano w wykładach i warsztatach oraz podczas zbierania historii mówionych od osób współpracujących z Dormanem, a performatywny potencjał archiwum najpełniej wyraził się podczas wydarzenia „Archiwum Dormana. Inspiracje, praktyki, refleksje" (25-27 XI 2017). ${ }^{5}$ W 2018 odbył się cykl seminariów i warsztatów w ramach rezydencji badawczych (pod kierownictwem naukowym Marzenny Wiśniewskiej), a ich owocem są artykuły zebrane w tym zeszycie „Pamiętnika Teatralnego”. Podsumowaniem trzech lat projektu jest strona internetowa jandorman.pl, która systematycznie udostępnia zdigitalizowane i opisane zbiory Archiwum Dormana oraz opracowania problemowe, a dalsze poszerzanie pola badań jest celem Ogólnopolskiej Konferencji Naukowej „Teatr Jana Dormana - poszukiwania, inspiracje, refleksje” (Instytut Teatralny, 13-15 XII 2019).

W niniejszym tomie po raz pierwszy ukazuje się tak całościowa i szczegółowa kronika życia i twórczości Jana Dormana (opracowały Ewa Tomaszewska i Marzenna Wiśniewska). Prezentuje ona najważniejsze fakty biograficzne, twórczość sceniczną i działalność pedagogiczną oraz organizacyjną będzińskiego artysty, konteksty rozwoju jego idei teatralnych, recepcję poszczególnych przedstawień i filozofii uprawiania teatru. W centrum kroniki jest postać Dormana, dlatego z konieczności ograniczono zakres informacji związanych z prowadzonymi przez niego teatrami do spraw najważniejszych dla nakreślania artystycznej drogi i rozległości zainteresowań reżysera oraz pokazania intensywności jego życia, nieustannego bycia w podróży, równoległego zaangażowania w wiele przedsięwzięć, budowania wokół siebie szerokiego środowiska przyjaciół i promotorów. Podstawą opracowania były zbiory Archiwum Dormana - rękopisy i maszynopisy, dzienniki, sklejki przedstawień i wydarzeń, listy, luźne notatki, „Kronika Teatru Dzieci Zagłębia" i zapiski prowadzone przez Janinę Dorman, ponadto publikowane wypisy z zasobów archiwalnych Dormana, zebrane i opracowane w cyklu książek pod redakcją Iwony Dowsilas oraz dotychczasowe wydawnictwa poświęcone historii TDZ, opracowania krytycznoteatralne, artykuły i recenzje. W zapisie zastosowano układ chronologiczny (daty dzienne, ewentualnie nazwy miesięcy), dokonano przeglądu i wyjaśnienia rozbieżności w datach premier podawanych w różnych źródłach.

5 Archiwum Dormana. Inspiracje, praktyki, refleksje (26-26 listopada 2017), Instytut Teatralny im. Z. Raszewskiego, red. V. Siedlecka-Dorosz, M. Wiśniewska, issuu.com/instytut.teatralny/docs/ dorman broszura 15_11. Uczestnicy „Grupy roboczej”: Judyta Berłowska, Przemek Furdak, Diana Jonkisz, Weronika Łucyk, Kinga Maciejewska, Honorata Mierzejewska-Mikosza, Malwina M. Rusów, Małgorzata Skoczelas, Laura Sonik, Sebastian Świąder, Sława Targowska, Monika Tomczyk, Iwona Woźniak. Audiowizualny zapis wydarzenia: youtube.com/watch?v=9GJAV4-CYig. Zapis performansu Taśma ciekawa, koncepcja S. Świąder: youtube.com/watch?v=g_N3OHp7uD0. 
Zebrane w tomie teksty uczestników rezydencji badawczej to swoiste zbliżenia na spektakle i tematy, które nigdy wcześniej nie były poddane krytycznoteatralnej refleksji lub doczekały się jedynie skromnych opracowań, a są szczególnie istotne w perspektywie ostatniej dekady działalności teatralnej Dormana. Po raz pierwszy ukazują się analizy dwóch ważnych przedstawień: prapremierowej inscenizacji Powiedz, że jestem Hanny Krall (Teatr im. J. Szaniawskiego w Wałbrzychu, 1985), podejmującej wątek Holokaustu i pamięci Zagłady - pisze o tym Hubert Michalak, oraz ostatniego spektaklu, Nocy Walpurgi (Teatr Animacji w Jeleniej Górze, 1986), inspirowanej wieloletnią fascynacją Faustem Goethego, co prześledziła Marzenna Wiśniewska. Wielotomowe sklejki z ręcznie zapisywanymi scenariuszami i dziennikami pracy pozwoliły nie tylko odtworzyć kształt spektakli, po których zachowały się zaledwie pojedyncze recenzje, ale szczegółowo zobaczyć fazy procesu twórczego, metody reżyserskie Dormana, inspiracje i konteksty dla jego wyobraźni scenicznej, związek z wcześniejszymi przedstawieniami oraz relację $\mathrm{z}$ otaczającą rzeczywistością. W toku analizy materiałów archiwalnych interesującym wątkiem okazały się spektakle niezrealizowane, a niekiedy niemal gotowe do scenicznego spełnienia. Jest ich kilka w dorobku Dormana, ale wyróżnia się dopracowany inscenizacyjnie dramat Anny Świrszczyńskiej O kulawym bogu Hefajstosie, który stanowi część swoistego nurtu antycznego w poszukiwaniach repertuarowych będzińskiego reżysera, co pokazuje Justyna Biernat. Magdalena Figzał-Janikowska daje pierwsze szerokie opracowanie tematu muzyki w twórczości teatralnej Dormana, omawia cykl spektakli muzycznych, na który złożyły się premiery z początku lat osiemdziesiątych inspirowane w dużej mierze kompozycjami Karola Szymanowskiego, m.in. Harnasie (Teatr Lalek Banialuka w Bielsku-Białej, 1982) i Król Roger (Teatr Lalki i Aktora im. H. Ch. Andersena w Lublinie, 1982). Jedno z najgłośniejszych i szeroko opisanych przedstawień Dormana, Szczęśliwy ksiązęe, do którego artysta wytworzył wyjątkowo obszerną, powstającą w ciągu wielu lat dokumentację ,życia” spektaklu, dało asumpt Magdalenie Rewerendzie do rozważań o autoarchiwalnym charakterze teatru będzińskiego twórcy, archiwizacji jako strategii artystycznej i aktywizacji utrwalanych treści poprzez performans. Bardzo ważny i rzadko przywoływany w badaniach teatralnych zbiór archiwaliów wydobywa tekst Agaty Łukaszewicz poświęcony listom i rysunkom widzów dziecięcych, które poddane zostały rozczytaniu z perspektywy utrwalonej w nich percepcji i wyobraźni małych autorów oraz bezpośredniego świadectwa recepcji będzińskich przedstawień przez najmłodszą widownię.

Przedstawiony tom nie wyczerpuje tematów, które odsłania Archiwum Dormana, a raczej zaprasza do badania nieopisanych jeszcze zagadnień oraz otwierania nieoczywistych wątków i narracji. Na szersze opracowanie czekają między innymi: twórczość Witkacego w dorobku teatralnym reżysera, w tym happeningowe przedstawienie studenckie inspirowane Karaluchami (1980) oraz Odważna księżniczka wg Juweniliów (Teatr Baj Pomorski w Toruniu, 1985); udokumentowana 
w dziennikach praktyka Dormana jako wykładowcy, eksperymentalne strategie kształcenia studentów i przedstawienia dyplomowe; spektakle oparte na materiale poetyckim (np. Przed zaśnięciem... Rymy dziecięce, Państwowy Teatr Lalki „Tęcza” w Słupsku, 1980); scenografie Dormanów: Jana i Jacka; korespondencja; działalność społeczno-kulturalna i organizacyjna, a także wiele tematów szczegółowych i kontekstowych, jak domagająca się osobnego opracowania aktorska i reżyserska twórczość Janiny Dorman. Zapraszamy zatem do rozwijania badań, odwołując się do tytułu projektu: „Dorman. Archiwum otwarte”.

Wszystkie cytaty z rękopisów i maszynopisów dokumentacji zebranej w Archiwum Dormana i dostępnej w Instytucie Teatralnym oznaczono skrótem: AJD/IT. W cytatach z niepublikowanych tekstów Dormana dokonano niezbędnego opracowania redakcyjnego w zakresie poprawności językowej i interpunkcyjnej oraz ujednolicenia konwencji zapisu, zachowano natomiast graficzne wyróżnienia charakterystyczne dla sposobu pisania artysty. Cytowania za przedrukami zachowały konwencje edytorskie zastosowane w pierwotnej publikacji.

Projekt „Dorman. Archiwum otwarte” finansowany jest w ramach programu Konkurs im. Jana Dormana, realizowanego przez Instytut Teatralny im. Zbigniewa Raszewskiego w Warszawie ze środków Ministerstwa Kultury i Dziedzictwa Narodowego. 